\title{
Demonstration of Tissue Resident Memory CD8 T Cells in Insulitic Lesions in Adult Patients with Recent-Onset Type 1 Diabetes
}

\author{
Enida Kuric, * Peter Seiron, ${ }^{*}$ Lars Krogvold, ${ }^{\dagger \ddagger}$ Bjørn Edwin,,${ }^{\ddagger \S}$ Trond Buanes, ${ }^{\ddagger \|}$ Kristian F. Hanssen, ${ }^{\ddagger * *}$ Oskar Skog, * \\ Knut Dahl-Jørgensen, ${ }^{\dagger \ddagger}$ and Olle Korsgren*
}

\begin{abstract}
From the Department of Immunology, Genetics and Pathology, * Uppsala University, Uppsala, Sweden; the Divisions of Paediatric and Adolescent Medicine ${ }^{\dagger}$ and Cancer, Surgery and Transplantation," the Department of Surgery, ${ }^{\S}$ The Intervention Centre, and the Departments of Pathology and Endocrinology, ${ }^{* *}$ Oslo University Hospital, Oslo, Norway; and the Faculty of Medicine, ${ }^{\ddagger}$ University of Oslo, Oslo, Norway
\end{abstract}

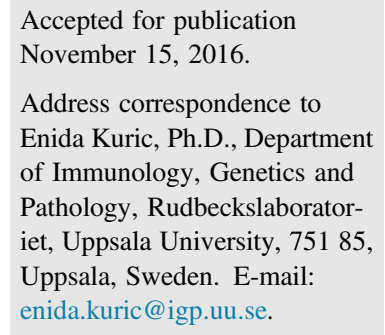

\begin{abstract}
Subtypes of $\mathrm{CD}^{+} \mathrm{T}$ cells in insulitic lesions in biopsy specimens from six subjects with recent-onset type 1 diabetes (T1D) and six nondiabetic matched controls were analyzed using simultaneous multicolor immunofluorescence. Also, insulitic islets based on accumulation of $\mathrm{CD}^{+}{ }^{+} \mathrm{T}$ cells were microdissected with laser-capture microscopy, and gene transcripts associated with inflammation and autoimmunity were analyzed. We found a substantial proportion, $43 \%$, of the $\operatorname{CD}^{+} \mathrm{T}$ cells in the insulitic lesions to display a tissue resident memory $T$ cell $\left(T_{R M}\right)\left(C D 8^{+} C D 69^{+} C D 103^{+}\right)$phenotype in T1D subjects. Most $T_{R M}$ cells were located in the insulitic lesion in the endocrine-exocrine interface. $T_{R M}$ cells were also sporadically found in islets of control subjects. Moreover, gene expression analysis showed a lack of active transcription of genes associated with acute inflammatory or cytotoxic T-cell responses. We present evidence that a substantial proportion of $T$ cells in insulitic lesions of recent-onset T1D patients are $\mathrm{T}_{\mathrm{RM}}$ cells and not classic cytotoxic $\mathrm{CD} 8^{+} \mathrm{T}$ cells. Our findings highlight the need for further analysis of the T cells involved in insulitis to elucidate their role in the etiology of T1D. (Am J Pathol 2017, 187: 581-588; http://dx.doi.org/10.1016/j.ajpath.2016.11.002)
\end{abstract}

The cellular and molecular mechanisms for $\beta$-cell loss and dysfunction in type 1 diabetes (T1D) remain unclear. Insulitis $^{1,2}$ has served as a morphological hallmark of T1D but, in contrast to findings in the prevailing animal models of the disease, insulitis in humans seems discrete and composed of only few immune cells predominantly located in the interface between the islets and the surrounding exocrine parenchyma. In subjects with recent-onset T1D, insulitis affects only few islets and is heterogeneously distributed within the gland. ${ }^{3-6}$ In a recent meta-analysis, discrete insulitis was reported in only $56 \%$ of subjects examined within the first month after diagnosis of T1D. ${ }^{7}$ Phenotypically, $\mathrm{CD}^{+} \mathrm{T}$ cells dominate the lesion, followed by $\mathrm{CD}^{+} 8^{+}$monocytes/macrophages. $\mathrm{CD}^{+} \mathrm{T}$ cells and $\mathrm{B}$ cells are less frequent, and regulatory $\mathrm{T}$ cells, natural killer cells, and plasma cells were found only rarely. ${ }^{1}$ No further subtyping of the $\mathrm{T}$ cells present in the insulitic lesions of subjects with T1D has been reported.
Despite intense research, the impact of $\mathrm{T}$ cells to disease development is under debate, and islet autoreactive $\mathrm{CD}^{+} \mathrm{T}$ cells in peripheral blood were recently found to be equally frequent in patients with recent-onset T1D when compared to healthy volunteers. ${ }^{8}$ Similarly, intervention therapies targeting these cells in subjects with recent-onset $\mathrm{T}_{1} \mathrm{D}^{9-12}$

Supported by South-Eastern Norway Regional Health Authority grant (K.D.-J.), the PEVNET Study Group funded by the European Union's Seventh Framework Programme (FP7/2007-2013) under grant 261441 PEVNET, the Swedish Medical Research Council (VR K2015-54X-1221919-4, 921-2014-7054), the Diabetes Wellness Foundation, the Novo Nordisk Foundation, the Åke Wiberg Foundation, the Tore Nilsson Foundation, the Swedish Diabetes Association, Gillbergska Stiftelsen, and Barndiabetesfonden. Human pancreatic biopsy specimens and isolated islets were obtained from The Nordic Network for Clinical Islet Transplantation, supported by the Swedish national strategic research initiative Excellence of Diabetes Research in Sweden and the Juvenile Diabetes Research Foundation.

Disclosures: None declared. 
cause no, or only transient, preservation of $\beta$-cell function. Collectively, these observations emphasize the need for further characterization of $\mathrm{T}$ cells in the insulitic lesions in subjects with recent-onset T1D.

Tissue resident memory $T$ cells $\left(T_{R M}\right.$ cells) constitute a subset of memory $\mathrm{T}$ cells defined by their inability to recirculate to lymph nodes and blood as other memory subsets. ${ }^{13,14}$ Hence, these cells persist for years at the site of previous infection and can provide rapid immune protection against reinfection via the same entry port. ${ }^{15}$ Accumulation of $\mathrm{T}_{\mathrm{RM}}$ cells in peripheral tissues (eg, lesions in psoriasis and vitiligo) can be identified by expression of integrin $\alpha \mathrm{E}$, CD103, and glycoprotein CD69. ${ }^{16}$ In psoriatic lesions, approximately half of epidermal $\mathrm{CD} 8^{+} \mathrm{T}$ cells express these $\mathrm{T}_{\mathrm{RM}}$ phenotypic markers. ${ }^{17,18}$ Recently, we demonstrated that $T_{R M}$ cells are present in low numbers in pancreatic samples from nondiabetic individuals without inflammation. ${ }^{19}$

Our previous finding of a distinctly different $\mathrm{T}$ - and B-cell gene expression pattern in infiltrated islets of patients with recent-onset T1D when compared with that observed in kidney transplant biopsy specimens with ongoing $\mathrm{T}$ cell-mediated allograft rejection ${ }^{5}$ raised the hypothesis that the $\mathrm{T}$ cells found in the insulitic lesions constitute unconventional T cells. A further characterization of the phenotypes of the $T$ cells present in the insulitic lesions from these patients was therefore performed using multicolor immunofluorescence and laser-capture microdissection with subsequent gene expression analysis.

\section{Materials and Methods}

\section{Patient Samples}

Pancreatic samples from six type 1 diabetic patients, the Diabetes Virus Detection (DiViD) study, ${ }^{20}$ were used in the present study. The DiViD study was approved by The Norwegian Governments Regional Ethics Committee. Written informed consent was obtained from all cases after oral and written information from the diabetologist and the surgeon separately. ${ }^{20}$ Three women and three men, 3 to 9 weeks after diagnosis, at an age between 24 and 35 years, were participating in the study. All patients were insulin dependent, were positive for glutamic acid decarboxylase autoantibodies, and had at least one high-risk human leukocyte antigen haplotype. Detailed clinical characteristics are described by Krogvold et al. ${ }^{20}$ Pancreatic tail biopsy specimens from six nondiabetic deceased organ donors, matched for age (range, 20 to 37 years; mean, 25.8 years), body mass index (range, 20.1 to $29.4 \mathrm{~kg} / \mathrm{m}^{2}$; mean, $25 \mathrm{~kg}$ / $\mathrm{m}^{2}$ ), and sex, served as controls. Consent for organ donation (for clinical transplantation and for use in research) was via online database (https://www.socialstyrelsen.se/donations registret/anmalan) or obtained verbally from the deceased's next of kin by the attending physician and documented in the medical records of the deceased in accordance with Swedish law and as approved by the Regional Ethics Committee (Dnr 2015/444).

\section{Immunofluorescence}

Biopsy specimens frozen in liquid nitrogen and kept at $-80^{\circ} \mathrm{C}$ were cut into sections (10 $\mu \mathrm{m}$ thick) and fixed in $1 \%$ methanol-free paraformaldehyde (Sigma Aldrich, Darmstadt, Germany). Blocking was performed with 5\% normal goat serum in tris-buffered saline supplemented with $0.05 \%$ Tween-20 (Dako, Glostrup, Denmark). Thereafter, sections were incubated with primary antibodies; details can be found in Table 1. After rinsing of unbound antibody, the sections were incubated with appropriate secondary antibodies raised in goat (dilution, 1:600) for 1 hour at room temperature, as shown in Table 1. Finally, sections were counterstained with DAPI (300 nmol/L; Life Technologies, Carlsbad, CA) and further processed for image analysis. Fluorescent signals were visualized using a confocal microscope (LSM700; Zeiss, Oberkochen, Germany). Human spleen and tonsil were used as positive controls. Omission of primary antibody served as negative control.

\section{Imaging and Data Analysis}

The whole insulin and glucagon stained section was scanned for each patient. This enabled identification of insulincontaining islets and insulin-deficient islets. In consecutive

Table 1 Detailed List of the Antibodies Used

\begin{tabular}{lllll}
\hline Name & Host & Dilution & Clone & Supplier \\
\hline Anti-CD8-AF488 & Mouse & $1: 100$ & C8/144B & Dako (Glostrup, Denmark) \\
Anti-CD103 & Rabbit & $1: 150$ & EPR4166 & Abcam (Cambridge, UK) \\
Anti-CD69 & Mouse & $1: 100$ & FN50 & Abd Serotec (0xford, UK) \\
Anti-insulin & Guinea pig & $1: 140$ & Polyclonal & Dako \\
Anti-glucagon & Rabbit & $1: 200$ & Polyclonal & LifeSpan BioSciences (Seattle, WA) \\
Anti-CD3 & Rabbit & $1: 50$ & Polyclonal & Dako \\
Anti-TCR $\gamma+$ TCR $\Delta$ & Mouse & $1: 20$ & EA6.E91 & Abcam \\
Anti-rabbit-AlexaFluor 647 & Donkey & $1: 400$ & Polyclonal & Life Technologies (Carlsbad, CA) \\
Anti-mouse-AlexaFlour 555 & Goat & $1: 400$ & Polyclonal & Life Technologies \\
Anti-guinea pig-AlexaFluor 488 & Goat & $1: 400$ & Polyclonal & Life Technologies \\
\hline
\end{tabular}

TCR, T-cell receptor. 

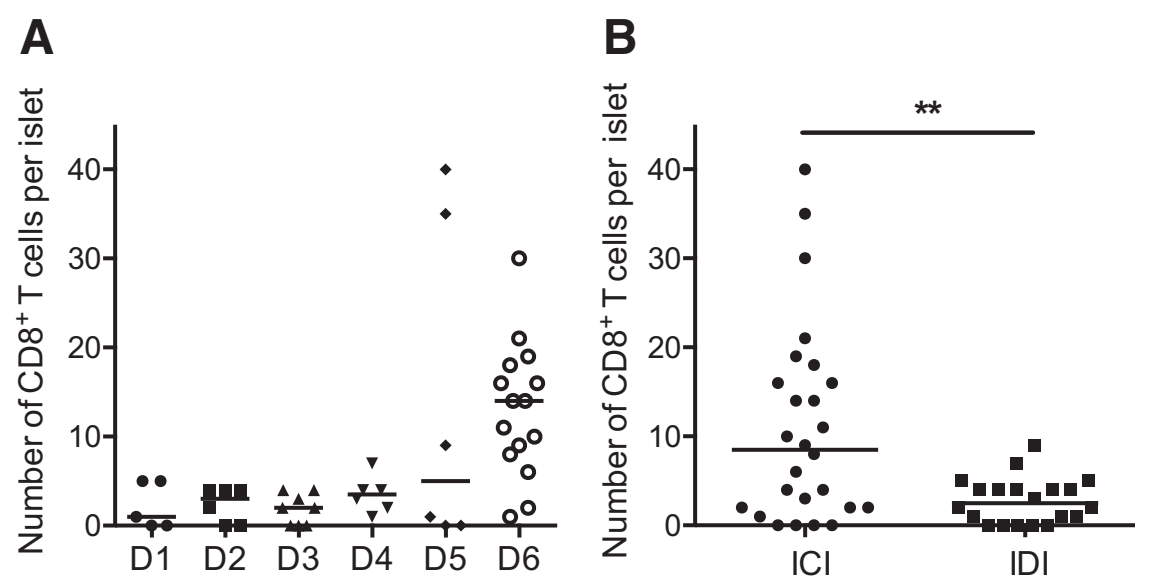

Figure $1 \mathrm{CDB}^{+} \mathrm{T}$ cells in insulitic lesions of recent-onset T1D subjects. The number of $\mathrm{CD}^{+} \mathrm{T}$ cells is displayed per islet in each of the six DiViD subjects (A) or in insulin-containing islets (ICIs) and insulin-deficient islets (IDIs) separately (B). Significance between ICIs and IDIs was tested with Mann-Whitney $U$ test. Data are presented as individual values with medians. ${ }^{* *} P<0.01$. D1 to D6, DiViD subjects 1 to 6 .

sections, these islets were triple stained for CD8, CD69, and CD103, and cells located in the endocrine-exocrine interface and within the islet parenchyma were counted manually using ImageJ software version 2.0.0 (NIH, Bethesda, MD; http://imagej.nih.gov/ij). ${ }^{21,22}$ All islets in each section were analyzed, and the number of CD8 and $\mathrm{T}_{\mathrm{RM}}$ cells in each islet is presented.

\section{Laser-Capture Microdissection and Transcriptome Analysis}

RNA isolated from the same islets microdissected previously from pancreatic tissue ${ }^{5}$ was used in this study. Briefly, frozen tissue samples from the pancreatic tail region were cut into sections and mounted onto Superfrost Plus glass (Menxel-Gläser, Braunschweig, Germany) or Arcturus PEN Membrane Glass Slides (Life Technologies) for immunohistochemistry and laser-capture microdissection, respectively. Consecutive sections were stained for CD3 or used for laser-capture microdissection to microdissect islets with insulitis $\left(\geq 15 \mathrm{CD}^{+}\right.$cells) from the diabetic samples and islets without insulitis from the nondiabetic samples. cDNA synthesis, preamplification of cDNA, and expression analysis was performed with kits from Qiagen (Sollentuna, Sweden), as described. ${ }^{5}$ A pathway-specific primer mix (Human Inflammatory Response and Autoimmunity, PBH077Z; Qiagen) was used for the preamplification, and a PCR array (Inflammatory Response and Autoimmunity, PAHS-077Z; Qiagen) was used for the expression analysis of 84 genes involved in inflammation. The expressions of $\beta$-actin $(A C T B)$, glyceraldehyde 3-phosphate dehydrogenase $(G A P D H)$, and 60S acidic ribosomal protein P0 (RPLPO) were used for normalization.

\section{Statistical Analysis}

Statistical differences between the groups were calculated using Mann-Whitney $U$ test using GraphPad Prism software version 6 (La Jolla, CA), and $P \leq 0.05$ was considered significant. The number of islets analyzed per subject is stated in the respective figure legend.

\section{Results}

$\mathrm{CD}^{+} \mathrm{T}$ cells were the most abundant $\mathrm{T}$-cell phenotype in the recent-onset $\mathrm{T} 1 \mathrm{D}$ subjects. The number of $\mathrm{CD} 8^{+} \mathrm{T}$ cells per islet was similar in four of six patients, whereas islets in patients 5 and 6 had markedly more $\mathrm{CD} 8^{+} \mathrm{T}$ cells (Figure 1A). Most of the $\mathrm{CD} 8^{+} \mathrm{T}$ cells were located in the endocrine-exocrine interface. When all islets from T1D subjects were analyzed and categorized on the basis of their insulin positivity, we found a significantly higher $(P=0.0059$, Mann-Whitney $U$ test $)$ number of $\mathrm{CD} 8^{+} \mathrm{T}$ cells per insulin-containing islet ( $n=26$; median, 9 cells) compared to insulin-deficient islet ( $n=20$; median, 3 cells) (Figure 1B).

Simultaneous staining for CD8, CD69, and CD103, markers expressed by $\mathrm{T}_{\mathrm{RM}}$ cells, ${ }^{16,23}$ revealed a $\mathrm{CD} 8{ }^{+} \mathrm{CD} 69^{+} \mathrm{CD} 103^{+}$population, as shown in Figure 2, $\mathrm{A}-\mathrm{C}$, demonstrating the presence of a substantial proportion of $\mathrm{T}_{\mathrm{RM}}$ cells in insulitic lesions of recently diagnosed T1D patients. $T_{R M}$ cells were sporadically found within the islet parenchyma but in markedly fewer numbers when compared with the $T_{R M}$ cells located in the exocrine and endocrine interface (Figure 2, A-C).

Quantification of $\mathrm{CD} 8^{+} \mathrm{CD} 69^{+} \mathrm{CD} 103^{+}$cells in the pancreas of T1D patients shows that on average $43 \%$ of all $\mathrm{CD}^{+} \mathrm{T}$ cells per islet had the phenotype of $\mathrm{T}_{\mathrm{RM}}$ cells and not conventional recirculating memory $\mathrm{T}$ cells (Figure 2D). Although expected variations between the six DiViD subjects as well as between individual islets were observed, 35 of 37 (94.6\%) analyzed islets with one or more $\mathrm{CD}^{+}$cells contained one or more $\mathrm{CD} 8^{+} \mathrm{CD} 69^{+} \mathrm{CD} 103^{+}$cell.

The proportion of $\mathrm{T}_{\mathrm{RM}}$ cells of all $\mathrm{CD} 8^{+} \mathrm{T}$ cells did not differ between insulin-containing islets and insulin-deficient islets (Figure 2E). More important, among the CD8 


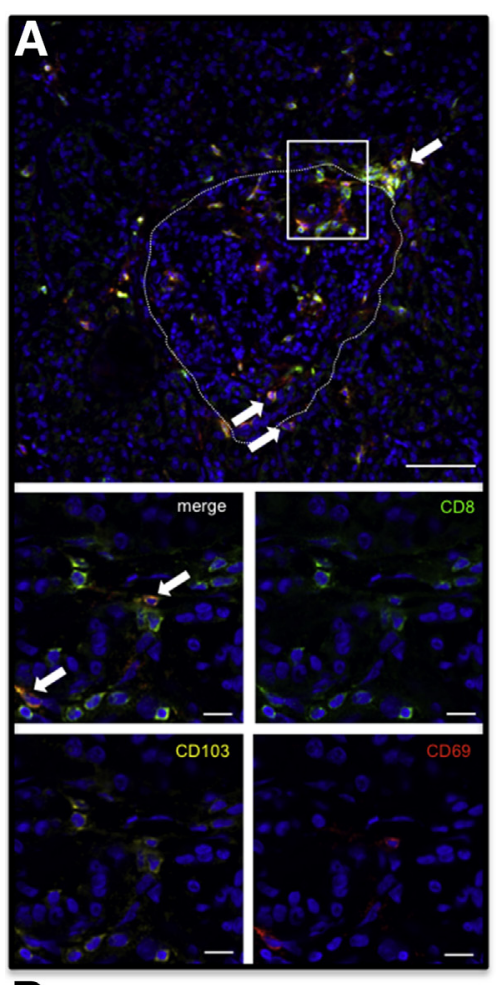

D

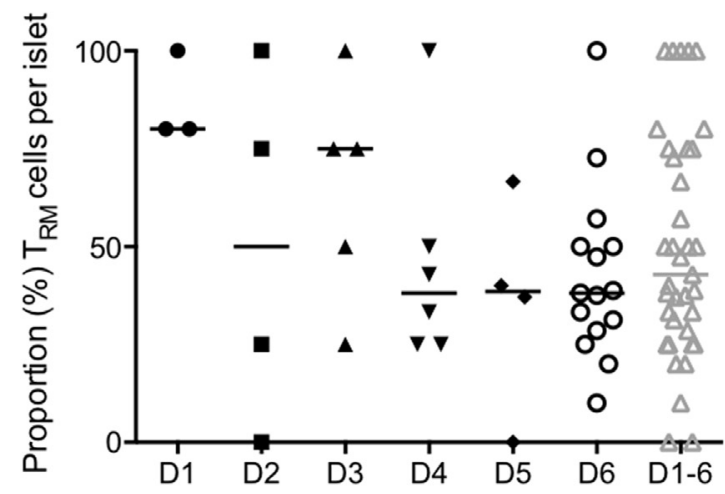

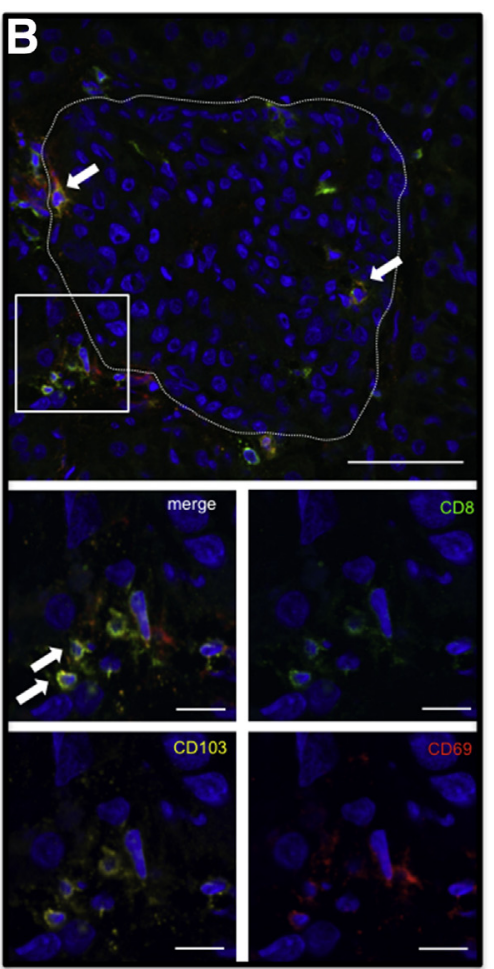
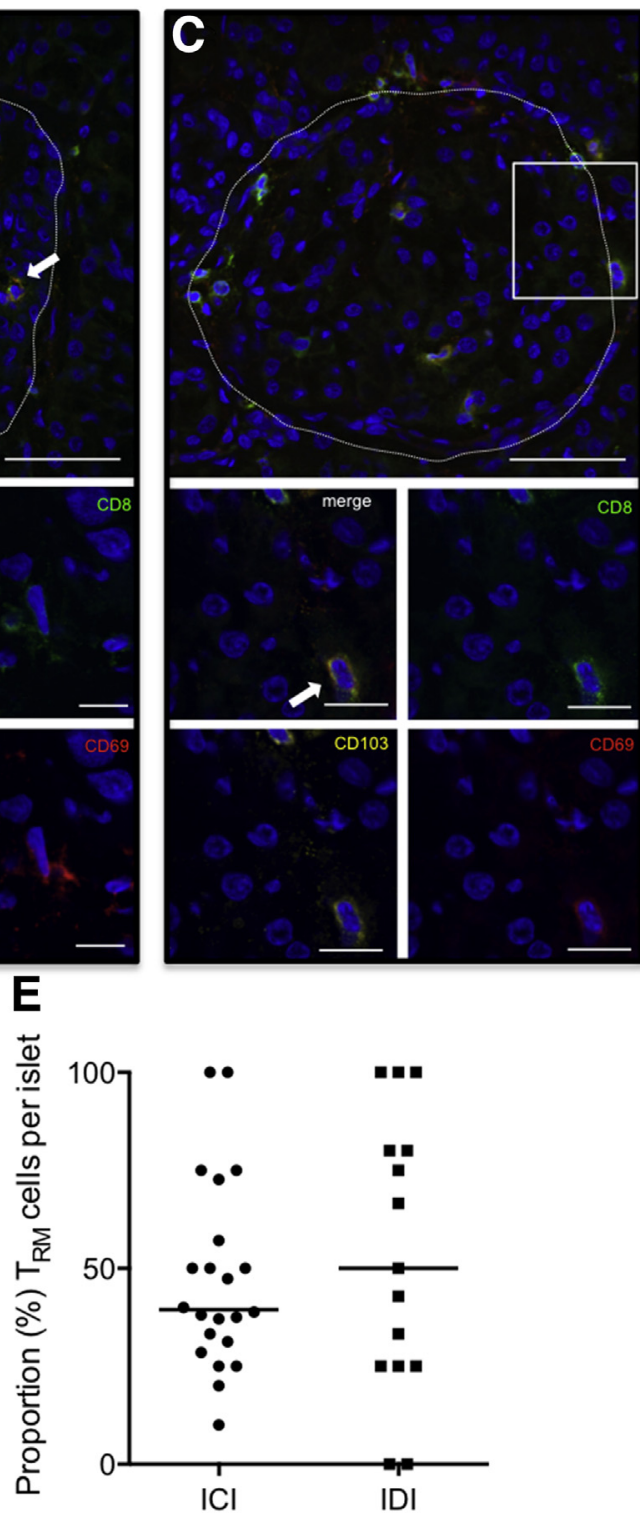

Figure 2 Tissue resident memory T cells ( $T_{R M}$ cells) in insulitic lesions of recent-onset T1D subjects. Confocal images of islets from DiViD subjects 5 (A), 6 (B), and 4 (C) stained for CD8 (green, AlexaFluor 488), CD103 (yellow, Alexafluor 555), and CD69 (red, AlexaFluor 647) and DAPI. In A-C, the boxed areas are displayed with higher magnification in the images below. Islets are indicated with a dashed line, and arrows indicate $T_{R M}\left(C D 8^{+} C D 69^{+} C D 103^{+}\right)$cells. The proportion of CD8 ${ }^{+} T$ cells showing a $\mathrm{T}_{\mathrm{RM}}$ phenotype is displayed per islet in each of the six DiViD subjects (D) or in insulin-containing islets (ICIs) and insulindeficient islets (IDIs) separately (E). Islets with no $C D 8^{+}$T cells were excluded. Data are presented as individual values with medians $(\mathbf{D}$ and $\mathbf{E}) . n=9(\mathbf{D}$ and E, islets with no CD8 ${ }^{+}$T cells). Scale bars: $100 \mu \mathrm{m}$ (A, B, and C, top images); $20 \mu \mathrm{m}$ (A, B, and C, bottom images). D1 to D6, DiViD subjects 1 to 6 .

population analyzed, no $\mathrm{CD} 103^{-}$cells were $\mathrm{CD} 69^{+}$, suggesting absence of recently activated conventional $\mathrm{CD} 8^{+} \mathrm{T}$ cells $^{24}$ in the insulitic lesions of T1D subjects. $\gamma \Delta \mathrm{T}$ cells were observed only rarely in the pancreas from T1D subjects, in the endocrine-exocrine interface or in the pancreatic parenchyma.

Although markedly fewer compared to T1D subjects, $\mathrm{CD}^{+}{ }^{+} \mathrm{CD} 69^{+} \mathrm{CD} 103^{+}$cells were also found in islets of control subjects (Figure 3), which corroborates a resident T-cell phenotype. More specific, of 44 islets examined, 21 (48\%) had at least one $\mathrm{CD}^{+} \mathrm{T}$ cell (Figure 3); 19 of these 21 CD8 T-cell containing islets had one or more
$\mathrm{CD}^{+} \mathrm{CD}^{+} 9^{+} \mathrm{CD} 103^{+} \mathrm{T}_{\mathrm{RM}}$ cells (Figure 3 ), suggesting minimal patrolling of recirculating $\mathrm{T}$ cells.

Expression analysis of genes associated with inflammation and autoimmunity of insulitic islets revealed that 19 genes of the 84 genes in the array were not detected in insulitic islets of any T1D subjects and several were at the border of detection limit (Figure 4A). Surprisingly, the expression of genes associated with an acute cytotoxic response, such as TNF, CCR7, LTA, and ILIA or activated cytotoxic T cells (IL2R, CD4OLG, and FASLG), were not detected in any T1D subjects. However, genes encoding cytokines more related to inflammation and innate immune 
A

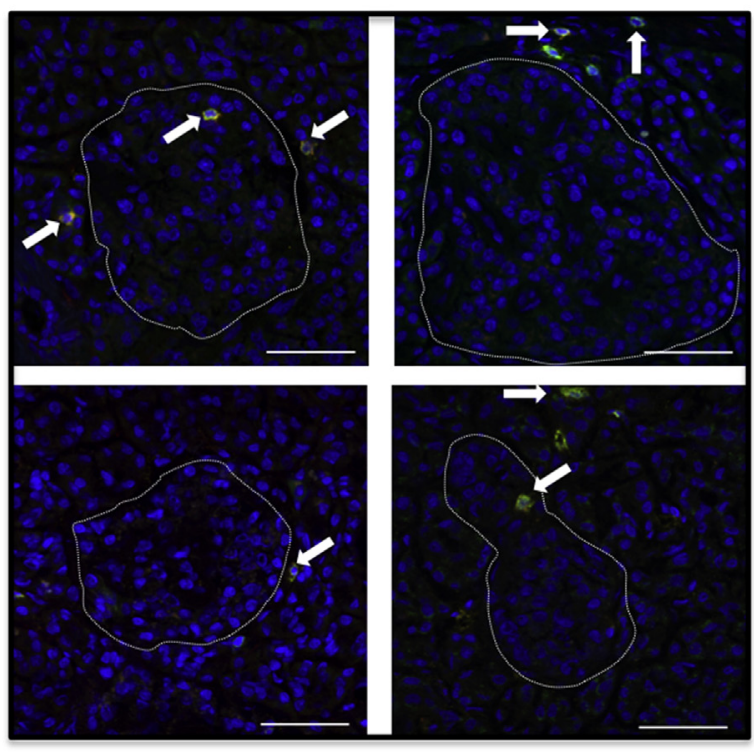

B

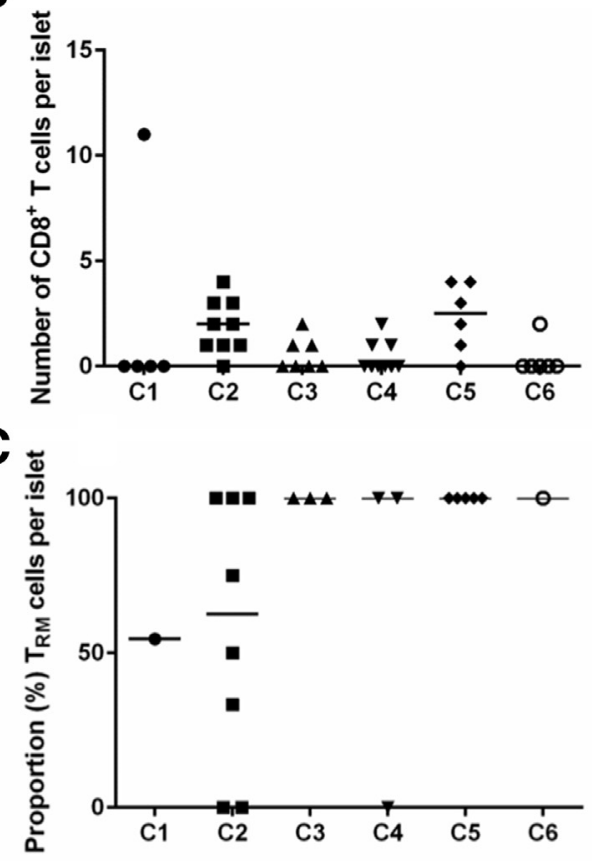

Figure 3 Tissue resident memory T cells ( $T_{R M}$ cells) in pancreata of nondiabetic donors. A: Confocal images of islets from four different nondiabetic control subjects stained for CD8 (green, AlexaFluor 488), CD103 (yellow, AlexaFluor 555), and CD69 (red, AlexaFluor 647) and DAPI. Islets are indicated with a dashed line, and arrows indicate $\mathrm{T}_{\mathrm{RM}}\left(\mathrm{CD} 8^{+} \mathrm{CD} 69^{+} \mathrm{CD} 103^{+}\right)$cells. $\mathrm{B}$ and $\mathrm{C}$ : The number of $\mathrm{CD} 8^{+} \mathrm{T}$ cells $(\mathbf{B})$ and the proportion of $\mathrm{CD} 8^{+} \mathrm{T}$ cells with a $\mathrm{T}_{\mathrm{RM}}$ phenotype $(\mathrm{C})$ are displayed per islet in each of six nondiabetic controls. Each dot represents an individual islet. Data are presented as individual values with medians. Scale bar $=100 \mu \mathrm{m}(\mathbf{A})$. C1 to C6, controls 1 to 6 .

responses (eg, IFNG, IL18, IL22, and IL15), chemokines, and ligands CXCL1, CCL11, CXCL9, CCL19, CCL7, CCL5, and CCL4 were up-regulated in insulitic islets of T1D subjects compared to noninsulitic islets from nondiabetic control donors, as shown in Figure 4, A and B.

\section{Discussion}

Our understanding of different T-cell subsets has markedly increased during the previous decade. Herein, we present evidence supporting the presence of a substantial proportion of $T_{R M}$ cells in the insulitic lesions in biopsy specimens from adult subjects with recent-onset T1D. In fact, $T_{R M}$ cells were found in pancreata of all T1D subjects from the DiViD cohort and represent on average approximately $40 \%$ of the total number of $\mathrm{CD}^{+} \mathrm{T}$ cells per islet, a proportion of $\mathrm{T}_{\mathrm{RM}}$ cells similar to that previously described in skin lesions of psoriasis. ${ }^{18}$

These findings, together with the relatively low prevalence of insulitis, ${ }^{2,7}$ in recent-onset T1D subjects and the fact that most of the $\mathrm{T}$ cells are residing in the islet-exocrine interface ${ }^{2,5,6}$ have implications for the prevailing view on the etiology of T1D, encompassing a crucial role for autoreactive cytotoxic $\mathrm{CD} 8^{+} \mathrm{T}$ cells specifically targeting the insulin-producing cells. ${ }^{25,26}$ Presence of autoreactive $\mathrm{CD} 8^{+} \mathrm{T}$ cells in islets of T1D subjects was shown by Coppieters et $\mathrm{al}^{25}$; however, numbers of $\mathrm{CD}^{+} \mathrm{T}$ cells were low, with no difference between subjects with recent-onset T1D and subjects with long-standing T1D. Also, because no quantification, nor further subtyping or assessment of activation, of the autoreactive $\mathrm{CD} 8^{+} \mathrm{T}$ cells in respective subjects was performed, the specificity and phenotype of most insulitic $\mathrm{T}$ cells remain unknown.

In vitro characterization of circulating autoreactive $\mathrm{CD} 8^{+}$ $\mathrm{T}$ cells shows ultra-low-affinity binding to the islet autoantigens and huge promiscuity. ${ }^{26,27}$ Despite these observations, these cells are able to kill human $\beta$ cells in vitro. ${ }^{26,28}$ However, the authors conclude that "such weak agonists will not generally be physiologically significant unless presented at very high copy numbers.. ${ }^{, 7, p .1175}$ In line with these observations, analysis in peripheral blood revealed autoreactive $\mathrm{CD}^{+} \mathrm{T}$ cells to be equally frequent in patients with recent-onset T1D and matched healthy volunteers, ${ }^{8}$ suggesting that the presence of a small number of autoreactive $\mathrm{T}$ cells is not sufficient for initiation of an autoimmune attack and development of T1D.

Experimental evidence clearly indicates that $\mathrm{T}_{\mathrm{RM}}$ cells are left remaining at the site or in close vicinity of previous infections in the absence of ongoing antigen presentation as a means to rapidly mobilize and recall an immune response if reinfection occurs via the same entry port. ${ }^{29,30}$ The substantial proportion of $T_{R M}$ cells in the islets of recent-onset T1D subjects reported herein may suggest involvement of an infectious agent in the development of $\mathrm{T}^{1} \mathrm{D}^{4,31-33}$ and a 
A

Type 1 diabetes

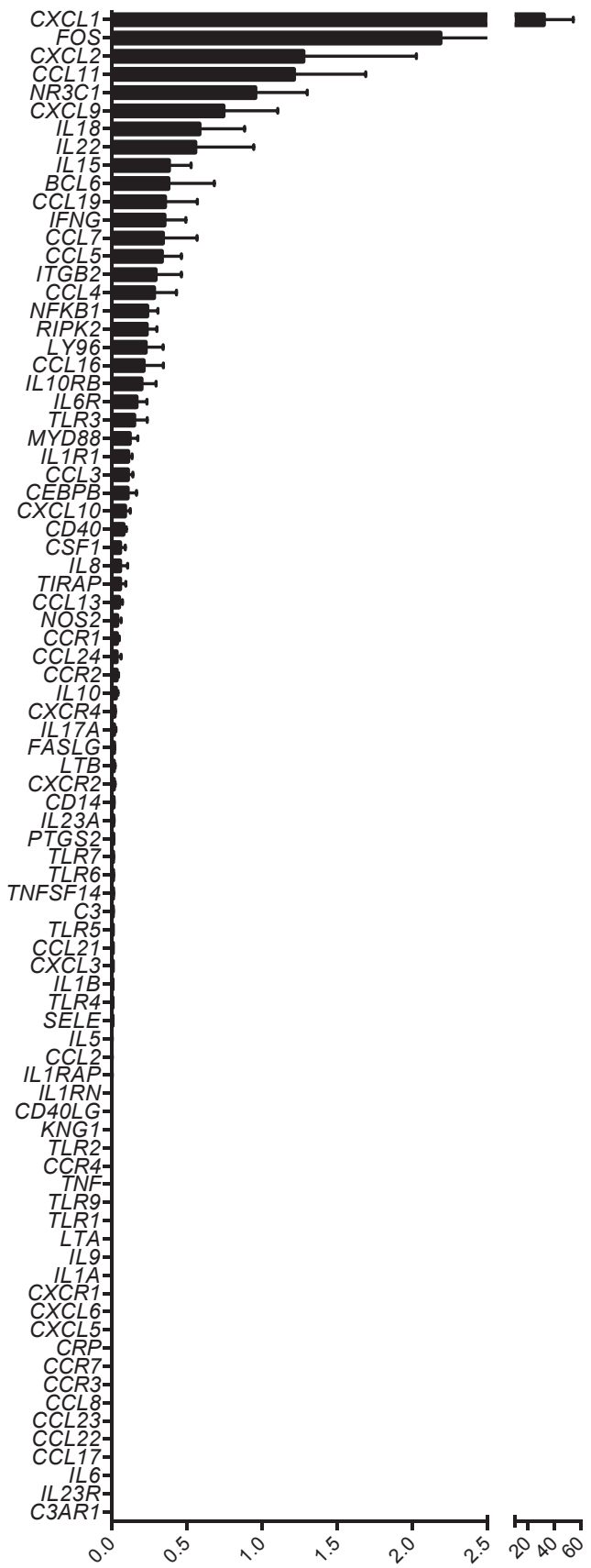

B

Control

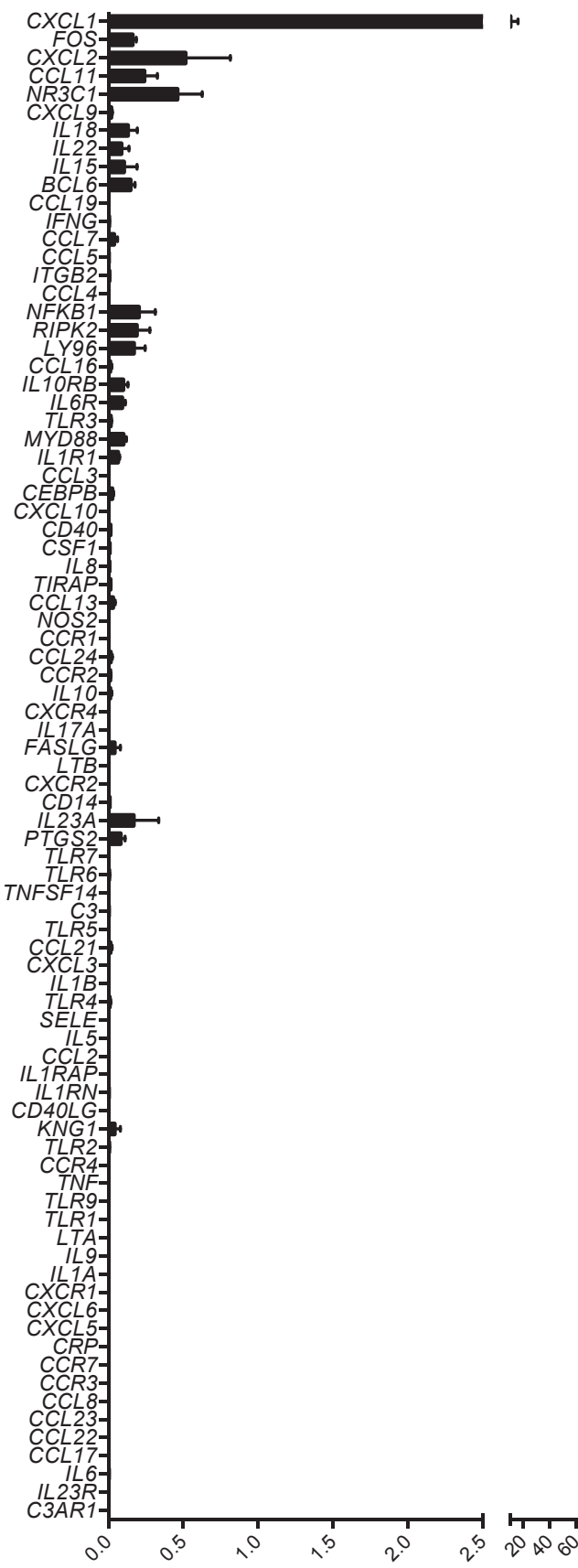

Figure 4 Expression of genes involved in inflammation and autoimmunity. Insulitic pancreatic islets from six recent-onset T1D subjects (A) and islets from six matched control organ donors (B). The expressions of $\beta$-actin (ACTB), glyceraldehyde 3-phosphate dehydrogenase (GAPDH), and 60S acidic ribosomal protein PO (RPLPO) were used for normalization.

significant role of $\mathrm{T}_{\mathrm{RM}}$ cells. However, a causative infectious agent in T1D remains to be demonstrated.

The function of human $\mathrm{T}_{\mathrm{RM}}$ cells is so far best described in psoriasis skin lesions, where $\mathrm{CD} 8^{+} \mathrm{CD} 103^{+} \mathrm{T}_{\mathrm{RM}}$ cells, when restimulated, show potent effector function by significant production of interferon- $\gamma$, tumor necrosis factor- $\alpha$, IL-17, IL-22, and IL-4 compared to recirculating T cells, but exhibit a lower proliferative capacity compared to the $\mathrm{CD}_{103^{-}}$resident population. ${ }^{29}$ In addition, inflammatory genes remained up-regulated in resolved lesions at least 3 months after systemic anti-tumor necrosis factor- $\alpha$ treatment. $^{18,34}$

From our data, it is not possible to define the functional status of the $T_{R M}$ cells because microdissection was not 
selectively based on $\mathrm{T}_{\mathrm{RM}}$ cells. However, in line with previously reported data, ${ }^{5} F A S L G,{ }^{35} T N F,{ }^{24}$ and $C D 154$ could not be detected in T1D subjects and, together with the lack of $\mathrm{CD} 8^{+} \mathrm{CD} 69^{+} \mathrm{CD} 103^{-} \mathrm{T}$ cells, in the insulitic lesions, our findings argue against an ongoing conventional cytotoxic CD8 T-cell response. Although it is not feasible to directly translate the gene expression data to the $\mathrm{T}_{\mathrm{RM}}$ cells found in the insulitic lesions, it is intriguing to speculate that the levels of IFNG, IL22, IL15, and ILI8 observed are because of low-grade activation of the $\mathrm{T}_{\mathrm{RM}}$ cells present in the isletexocrine interface. Nevertheless, contribution from other cell types cannot be neglected.

The diabetic pancreata included in this study were from adult subjects diagnosed with type 1 diabetes based on clinical and laboratory (presence of autoantibodies) criteria. It has been shown previously that the insulitic profile differs between adults and children diagnosed with T1D. ${ }^{36,37}$ Whether $T_{R M}$ cells are a general feature of the insulitis in T1D, or if it defines only a subtype of T1D patients diagnosed as adults, remains to be determined.

In summary, we present data demonstrating the presence of a substantial proportion of $T_{R M}$ cells, a subtype of $T$ cells not previously described in the insulitic lesions of T1D. Our findings suggest that a large proportion of the $\mathrm{CD} 8^{+} \mathrm{T}$ cells present in the insulitic lesions, at least in adult patients, are part of a protective, not cytotoxic, immune response. This study highlights the need for further characterization of the insulitic lesions, to elucidate the role of these cells in the etiology of T1D and to allow development of effective means to intervene in disease progression.

\section{Acknowledgments}

We thank specialist nurse Trine Roald (Oslo University Hospital, Oslo, Norway), whose invaluable efforts were essential to the success of the DiViD study; and Biological Visualization at Uppsala University for excellent technical assistance with confocal microscopy.

E.K. participated in the study design, performed experiments, data analysis, and interpretation, and wrote the manuscript; P.S. performed the experiments, data analysis, and interpretation and participated in writing the manuscript; L.K. was responsible for clinical coordination, the recruitment of patients, and data collection, analysis, and interpretation, and participated in writing the manuscript; B.E. and T.B. performed the surgery and participated in writing the manuscript; K.F.H. was involved in the coordination of the DiViD study and participated in writing the manuscript; K.D.-J. is the principal investigator of the DiViD study and, as such, was responsible for design of the DiViD study, funding, regulatory issues, and international collaboration and participated in writing the manuscript; O.S. participated in the study design, data interpretation, and writing of the manuscript; O.K. designed the study, interpreted the data, and wrote the manuscript; O.K. is the guarantor of this work and had full access to all of the data in the study and takes responsibility for the integrity of the data and the accuracy of the data analysis.

\section{References}

1. Willcox A, Richardson SJ, Bone AJ, Foulis AK, Morgan NG: Analysis of islet inflammation in human type 1 diabetes. Clin Exp Immunol 2009, 155:173-181

2. In't Veld P: Insulitis in human type 1 diabetes: a comparison between patients and animal models. Semin Immunopathol 2014, 36:569-579

3. Foulis AK, Frier BM: Pancreatic endocrine-exocrine function in diabetes: an old alliance disturbed. Diabet Med 1984, 1:263-266

4. Korsgren S, Molin Y, Salmela K, Lundgren T, Melhus A, Korsgren O: On the etiology of type 1 diabetes: a new animal model signifying a decisive role for bacteria eliciting an adverse innate immunity response. Am J Pathol 2012, 181:1735-1748

5. Krogvold L, Wiberg A, Edwin B, Buanes T, Jahnsen FL, Hanssen KF, Larsson E, Korsgren O, Skog O, Dahl-Jorgensen K: Insulitis and characterisation of infiltrating $\mathrm{T}$ cells in surgical pancreatic tail resections from patients at onset of type 1 diabetes. Diabetologia 2016 , 59:492-501

6. Reddy S, Zeng N, Al-Diery $\mathrm{H}$, Jung $\mathrm{D}$, Yeu C, Joret MO, Merrilees MJ, Wu F: Analysis of peri-islet CD45-positive leucocytic infiltrates in long-standing type 1 diabetic patients: additional data regarding cause of death. Diabetologia 2015, 58:1959

7. In't Veld P: Insulitis in human type 1 diabetes: the quest for an elusive lesion. Islets 2011, 3:131-138

8. Skowera A, Ladell K, McLaren JE, Dolton G, Matthews KK, Gostick E, Kronenberg-Versteeg D, Eichmann M, Knight RR, Heck S, Powrie J, Bingley PJ, Dayan CM, Miles JJ, Sewell AK, Price DA, Peakman M: Beta-Cell-specific CD8 T cell phenotype in type 1 diabetes reflects chronic autoantigen exposure. Diabetes 2015, 64: 916-925

9. Keymeulen B, Vandemeulebroucke E, Ziegler AG, Mathieu C, Kaufman L, Hale G, Gorus F, Goldman M, Walter M, Candon S, Schandene L, Crenier L, De Block C, Seigneurin JM, De Pauw P, Pierard D, Weets I, Rebello P, Bird P, Berrie E, Frewin M, Waldmann H, Bach JF, Pipeleers D, Chatenoud L: Insulin needs after CD3-antibody therapy in new-onset type 1 diabetes. N Engl J Med 2005, 352:2598-2608

10. Kaufman A, Herold KC: Anti-CD3 mAbs for treatment of type 1 diabetes. Diabetes Metab Res Rev 2009, 25:302-306

11. Keymeulen B, Walter M, Mathieu C, Kaufman L, Gorus F, Hilbrands R, Vandemeulebroucke E, Van de Velde U, Crenier L, De Block C, Candon S, Waldmann H, Ziegler AG, Chatenoud L, Pipeleers D: Four-year metabolic outcome of a randomised controlled CD3-antibody trial in recent-onset type 1 diabetic patients depends on their age and baseline residual beta cell mass. Diabetologia 2010, 53: 614-623

12. Gitelman SE, Gottlieb PA, Felner EI, Willi SM, Fisher LK, Moran A, Gottschalk M, Moore WV, Pinckney A, Keyes-Elstein L, Harris KM, Kanaparthi S, Phippard D, Ding L, Bluestone JA, Ehlers MR; ITN START Study Team: Antithymocyte globulin therapy for patients with recent-onset type 1 diabetes: 2 year results of a randomised trial. Diabetologia 2016, 59:1153-1161

13. Masopust D, Vezys V, Marzo AL, Lefrancois L: Preferential localization of effector memory cells in nonlymphoid tissue. Science 2001, 291:2413-2417

14. Sathaliyawala T, Kubota M, Yudanin N, Turner D, Camp P, Thome JJ Bickham KL, Lerner H, Goldstein M, Sykes M, Kato T, Farber DL: Distribution and compartmentalization of human circulating and tissueresident memory T cell subsets. Immunity 2013, 38:187-197

15. Clark RA: Resident memory T cells in human health and disease. Sci Transl Med 2015, 7:269rv1 
16. Mackay LK, Rahimpour A, Ma JZ, Collins N, Stock AT, Hafon ML, Vega-Ramos J, Lauzurica P, Mueller SN, Stefanovic T, Tscharke DC, Heath WR, Inouye M, Carbone FR, Gebhardt T: The developmental pathway for CD103(+)CD8+ tissue-resident memory T cells of skin. Nat Immunol 2013, 14:1294-1301

17. Teraki Y, Shiohara T: Preferential expression of alphaEbeta7 integrin (CD103) on CD8 $+\mathrm{T}$ cells in the psoriatic epidermis: regulation by interleukins 4 and 12 and transforming growth factor-beta. Br J Dermatol 2002, 147:1118-1126

18. Cheuk S, Wiken M, Blomqvist L, Nylen S, Talme T, Stahle M, Eidsmo L: Epidermal Th22 and Tc17 cells form a localized disease memory in clinically healed psoriasis. J Immunol 2014, 192:3111-3120

19. Radenkovic M, Uvebrant K, Skog O, Sarmiento L, Avartsson J, Storm P, Vickman P, Bertilsson PA, Fex M, Korsgren O, Cilio CM: Characterization of resident lymphocytes in human pancreatic islets. Clin Exp Immunol 2016, [Epub ahead of print], http://dx.doi.org/10. $1111 /$ cei.12892

20. Krogvold L, Edwin B, Buanes T, Ludvigsson J, Korsgren O, Hyoty H, Frisk G, Hanssen KF, Dahl-Jorgensen K: Pancreatic biopsy by minimal tail resection in live adult patients at the onset of type 1 diabetes: experiences from the DiViD study. Diabetologia 2014, 57:841-843

21. Schindelin J, Rueden CT, Hiner MC, Eliceiri KW: The ImageJ ecosystem: an open platform for biomedical image analysis. Mol Reprod Dev 2015, 82:518-529

22. Schindelin J, Arganda-Carreras I, Frise E, Kaynig V, Longair M, Pietzsch T, Preibisch S, Rueden C, Saalfeld S, Schmid B, Tinevez JY, White DJ, Hartenstein V, Eliceiri K, Tomancak P, Cardona A: Fiji: an open-source platform for biological-image analysis. Nat Methods 2012, 9:676-682

23. Owens GC, Chang JW, Huynh MN, Chirwa T, Vinters HV, Mathern GW: Evidence for resident memory $\mathrm{T}$ cells in Rasmussen encephalitis. Front Immunol 2016, 7:64

24. Slifka MK, Whitton JL: Activated and memory CD $8+$ T cells can be distinguished by their cytokine profiles and phenotypic markers. J Immunol 2000, 164:208-216

25. Coppieters KT, Dotta F, Amirian N, Campbell PD, Kay TW, Atkinson MA, Roep BO, von Herrath MG: Demonstration of isletautoreactive CD8 $\mathrm{T}$ cells in insulitic lesions from recent onset and long-term type 1 diabetes patients. J Exp Med 2012, 209:51-60

26. Bulek AM, Cole DK, Skowera A, Dolton G, Gras S, Madura F, Fuller A, Miles JJ, Gostick E, Price DA, Drijfhout JW, Knight RR, Huang GC, Lissin N, Molloy PE, Wooldridge L, Jakobsen BK, Rossjohn J, Peakman M, Rizkallah PJ, Sewell AK: Structural basis for the killing of human beta cells by $\mathrm{CD} 8(+) \mathrm{T}$ cells in type 1 diabetes. Nat Immunol 2012, 13:283-289

27. Wooldridge L, Ekeruche-Makinde J, van den Berg HA, Skowera A, Miles JJ, Tan MP, Dolton G, Clement M, Llewellyn-Lacey S, Price DA, Peakman M, Sewell AK: A single autoimmune T cell receptor recognizes more than a million different peptides. J Biol Chem 2012, 287:1168-1177

28. Knight RR, Kronenberg D, Zhao M, Huang GC, Eichmann M, Bulek A, Wooldridge L, Cole DK, Sewell AK, Peakman M, Skowera A: Human beta-cell killing by autoreactive preproinsulinspecific CD8 T cells is predominantly granule-mediated with the potency dependent upon T-cell receptor avidity. Diabetes 2013, 62: 205-213

29. Watanabe R, Gehad A, Yang C, Scott LL, Teague JE, Schlapbach C, Elco CP, Huang V, Matos TR, Kupper TS, Clark RA: Human skin is protected by four functionally and phenotypically discrete populations of resident and recirculating memory T cells. Sci Transl Med 2015, 7: 279ra39

30. Mackay LK, Stock AT, Ma JZ, Jones CM, Kent SJ, Mueller SN, Heath WR, Carbone FR, Gebhardt T: Long-lived epithelial immunity by tissue-resident memory T (TRM) cells in the absence of persisting local antigen presentation. Proc Natl Acad Sci U S A 2012, 109: 7037-7042

31. Vatanen T, Kostic AD, d'Hennezel E, Siljander H, Franzosa EA, Yassour M, Kolde R, Vlamakis H, Arthur TD, Hamalainen AM, Peet A, Tillmann V, Uibo R, Mokurov S, Dorshakova N, Ilonen J, Virtanen SM, Szabo SJ, Porter JA, Lahdesmaki H, Huttenhower C, Gevers D, Cullen TW, Knip M; DIABIMMUNE Study Group, Xavier RJ: Variation in microbiome LPS immunogenicity contributes to autoimmunity in humans. Cell 2016, 165:1551

32. Ylipaasto $\mathrm{P}$, Klingel $\mathrm{K}$, Lindberg AM, Otonkoski T, Kandolf R, Hovi T, Roivainen M: Enterovirus infection in human pancreatic islet cells, islet tropism in vivo and receptor involvement in cultured islet beta cells. Diabetologia 2004, 47:225-239

33. Tauriainen S, Oikarinen S, Oikarinen M, Hyoty H: Enteroviruses in the pathogenesis of type 1 diabetes. Semin Immunopathol 2011, 33:45-55

34. Suarez-Farinas M, Fuentes-Duculan J, Lowes MA, Krueger JG: Resolved psoriasis lesions retain expression of a subset of diseaserelated genes. J Invest Dermatol 2011, 131:391-400

35. Kagi D, Vignaux F, Ledermann B, Burki K, Depraetere V, Nagata S, Hengartner H, Golstein P: Fas and perforin pathways as major mechanisms of T cell-mediated cytotoxicity. Science 1994, 265: $528-530$

36. Leete P, Willcox A, Krogvold L, Dahl-Jorgensen K, Foulis AK, Richardson SJ, Morgan NG: Differential insulitic profiles determine the extent of beta-cell destruction and the age at onset of type 1 diabetes. Diabetes 2016, 65:1362-1369

37. Arif S, Leete P, Nguyen V, Marks K, Nor NM, Estorninho M, Kronenberg-Versteeg D, Bingley PJ, Todd JA, Guy C, Dunger DB, Powrie J, Willcox A, Foulis AK, Richardson SJ, de Rinaldis E, Morgan NG, Lorenc A, Peakman M: Blood and islet phenotypes indicate immunological heterogeneity in type 1 diabetes. Diabetes 2014, 63:3835-3845 